\title{
Смешанные хиральные неподвижные фазы в хроматографии (обзор)
}

\author{
Федорова И.А., Шаповалова Е.Н., Шпигун О.А. \\ Московский государственный университет им. М.В. Ломоносова, Москва
}

Поступила в редакцию 20.06.2018 г.

DOI: https://doi.org/10.17308/sorpchrom.2018.18/589

Обсуждается использование смешанных селекторов в газовой и высокоэффективной жидкостной хроматографии для разделения оптических изомеров. Они позволяют повысить универсальность хиральной фазы. В газовой хроматографии широко и успешно используются смеси модифицированного $\beta$-циклодекстрина. В ВЭЖХ наиболее изучены смешанные хиральные селекторы на основе низкомолекулярных селекторов и производных полисахаридов, в меньшей степени - белков и макроциклических антибиотиков.

Ключевые слова: хиральные смешанные неподвижные фазы, производные $\beta$ циклодекстрина, низкомолекулярные селекторы, полисахариды, эремомицин, ванкомицин, бычий сывороточный альбумин.

\section{Mixed chiral stationary phases for chromatography}

\author{
Fedorova I.A., Shapovalova E.N., Shpigun O.A. \\ Lomonosov Moscow State University, Moscow
}

Mixed stationary phases for the separation of enantiomers make possible to increase the universality of the chiral phase. They are used in liquid and gas chromatography. Mixed chiral selectors for gas chromatography are most often $\beta$-cyclodextrin derivatives, less often amino acid derivatives. In gas chromatography mixtures of modified $\beta$-cyclodextrins are widely and successfully used to separate the enantiomers of substances found in essential oils of plants and fruit, as well as $\mathrm{N}$-trifluoroacetyl-ethyl esters of amino acids. An averaged effect is often observed from each component of mixed chiral phase, but in some cases a synergistic effect is detected by the authors.

Mixed chiral selectors with low molecular weight selectors, derivatives of polysaccharides, proteins and macrocyclic antibiotics are most researched by HPLC. The combination of selectors in the stationary phase is determined largely by two factors: the ability to complement each other's enantioselective properties and the similarity of their immobilization on the matrix (most often it is silica gel). Chiral phase with human serum albumin and $\alpha 1$-glycoprotein allows you to separate the optical isomers of the cationic, anionic and neutral compounds, among them more than ten pharmaceutical drugs. Binary chiral selectors containing cellulose tris-benzoate, cellulose tris-(4-methylphenylcarbinol), cellulose tris-phenylcarbamate, cellulose tris(4-chlorpheniramine) and amylose tris-(3,5-dimethylphenylcarbamate) were also investigated. As a rule, mixed stationary phases have an average ability to separate enantiomers as compared to phases with a single chiral selector, but enantioselectivity is increased in some cases. It is important, that these phases could be analyzed by a $100 \%$ ethanol mobile phase. It is considered that a mixture of macrocyclic antibiotics (eremomycin and vancomycin) allows us to separate enantiomers of $\beta$-blockers and non-derivatized amino acids. Vancomycin separates enantiomers of $\beta$-blockers only, eremomycin separates amino acids enantiomers. The combination of eremomycin and bovine serum albumin (BSA) slightly changes the selectivity of enantiomer separation of profens. BSA on the sorbent surface eliminates the influence of proteins in the sample solution on profens determination. It simplifies a sample preparation during the analysis of biological fluids. 
Keywords: chiral mixed stationary phases, $\beta$-cyclodextrin derivatives, low molecular weight selectors, polysaccharides, eremomycin, vancomycin, bovine serum albumin.

\section{Введение}

Появление все большего количества хиральных сорбентов с селекторами различной природы, позволяющих разделять энантиомеры оптически активных веществ, заставляет задуматься о поиске универсального сорбента, который можно использовать для энантиоразделения большинства классов оптических соединений. На сегодняшний день шагом к решению этой задачи стало появление, так называемых, смешанных хиральных неподвижных фаз. Основное отличие таких фаз от обычной хиральной неподвижной фазы (ХНФ) заключается в том, что такая фаза содержит не один, а сразу несколько селекторов. Наиболее успешно такой подход реализован в капиллярной газовой хроматографии, важную роль в этом играет высокая эффективность капиллярных колонок.

1. Смешанные хиральные неподвижные фазы в газовой хроматографии. Наиболее популярные и селективные ХНФ для газовой хроматографии в качестве хирального селектора содержат производные $\beta$-циклодекстрина ( $\beta$-ЦД). Среди них ряд фаз содержат смеси различных $\beta$-ЦД. Авторы работы [1] синтезировали стационарные фазы для газовой хроматографии, содержащие перметилированный $\beta$-ЦД (колонка А), перпентилированный (колонка Б) $\beta$-ЦД и бинарную фазу, содержащую их смесь (колонка АБ). Производные $\beta$-ЦД наносили на кварцевые капиллярные колонки в растворе OV-1701 в качестве растворителя в соотношении $1: 4$ для колонок А и Б и в соотношении перметилированный $\beta$-ЦД : перпентилированный $\beta$-ЦД : OV-1701 $1: 1: 4$ для смешанной фазы. На полученных таким образом колонках было проведено разделение энантиомеров инданола, валина, аланина, дигидрокарвил ацетата. Валин и аланин определяли после их дериватизации с использованием трифторуксусного ангидрида и изопропилового спирта. Коэффициенты селективности для всех исследованных оптически активных веществ на колонке АБ со смешанной фазой больше, чем коэффициенты селективности, полученные на колонках А и Б. Так, например, коэффициент селективности для разделения энантиомеров производных валина на смешанной стационарной фазе составил 1.04 , тогда как на колонках с одним хиральным селектором коэффициенты равны 1.02. Коэффициент энантиоселективности дигидрокарвил ацетата на смешанной фазе 1.05 , на колонках А и Б он равен 1.02 и 1.00 соответственно. Эти данные указывают на улучшение распознавания энантиомеров исследованных соединений на смешанной фазе по сравнению с фазами только с одним производным $\beta$-ЦД.

Как правило, на смешанных фазах наблюдается усредненный эффект от соответствующих фаз с индивидуальными компонентами, однако в данной работе авторы наблюдали синергетический эффект. Причины этого могут заключаться в стерическом совпадении конформации молекул растворенного вещества и полостей производных циклодекстрина, а также наличием взаимодействий различных типов (дисперсионные, диполь-дипольные, $\pi-\pi$ взаимодействия, образование водородных связей).

Авторы работы [2] в качестве хиральных селекторов помимо перметилиро-

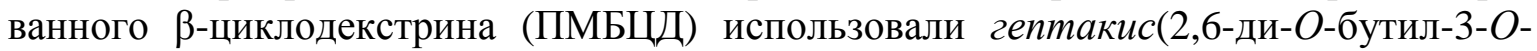
бутирил)- $\beta$-циклодекстрин (ДБББЦД) и гептакис $(2,6-$-ди- $O$-нонил-3-Oтрифторацетил)- $\beta$-циклодекстрин (ДНТБЦД) и синтезировали стационарные фазы:

- колонка А: $15 \%$ ПМБЦД + $85 \%$ OV-1701

- колонка Б: 50 \% ДБББЦД + 50 \% OV-1701 
- колонка В: 50 \% ДНТБЦД + 50 \% SE-54

- колонка АБ: $15 \%$ ПМБЦД + 50 \% ДБББЦД + 35 \% OV-1701

- колонка АВ: 15 \% ПМБЦД + 50 \% ДНТБЦД + 35 \% OV-1701

На полученных колонках разделяли оптические изомеры пиретроидных инсектицидов, которые являются синтетическими аналогами природных пиретринов. Тестовые соединения имеют два хиральных атома углерода в циклопропановом кольце (в частности, метиловый эфир хризантемовой кислоты (1), L-ментиловый эфир хризантемовой кислоты (2), метиловый эфир перметрина (3), метиловый (4) и этиловый (5) эфиры 3-(2,2,2-трихлорэтил)-2,2-диметилциклопропановой кислоты). При изучении энантиоразделения данных веществ авторы наблюдали синергетический эффект для фаз с двумя селекторами по сравнению с фазами с одним производным. Так, например, величина разрешения для (4) и (5) на колонках АБ и АВ выше, чем на колонках А, Б, В. Такой же эффект наблюдали и для транс-(3) на колонке АБ. Однако, для большинства тестовых рацематов полученные значения разрешения на колонке АБ были между значениями, полученными на колонках А и Б. Одним из достоинств колонки АБ стала возможность одновременного разделения диастереомеров и энантиомеров метилового эфира хризантемовой кислоты, тогда как на колонках А, Б с одним селектором это невозможно. По аналогии, диастереомеры и энантиомеры метилового эфира перметрина не могут быть разделены на колонках А, Б, В, но делятся с хорошим разрешением на смешанных колонках АБ и АВ.

Возможности гептакис (2,6-ди- $O$-метил-3- $O$-пентил)- $\beta$-циклодекстрина $(2,6-$ Мe-3-Pe- $\beta$-CD) $\quad$ и октакис(2,6-ди-O-метил-3-O-трифторацетил)- $\beta$-циклодекстрина (2,6-Me-3-TFAc- $\gamma$-CD) как хиральных селекторов в газовой хроматографии оценены в работе [3]. Синтезированная фаза Chiramix, содержащая оба селектора, позволила разделить энантиомеры компонентов персикового масла, а также смесь монотерпенов, спиртов, кетонов и лактонов лучше, чем фазы, содержащие только один из селекторов.

В работе [4] для синтеза смешанной стационарной фазы использовали гептакис(2,3-ди-O-метил-6-O-mpem-бутилдиметилсилил)- $\beta$-циклодекстрин $\quad$ и $\quad$ геnтакис(2,3-ди- $O$-ацетил-6-O-mpem-бутилдиметилсилил)- $\beta$-циклодекстрин, отличающиеся полярностью и, соответственно, энантиоразделяющими способностями. На такой фазе делили энантиомеры веществ, входящих в состав эфирных масел лаванды, апельсина, неролиевого масла, в частности лимонена, линалоола, его оксидов, линалилацетата, $(E)$-неролидола, $\alpha$ - и $\beta$-пиненов, терпинен-4-ола, $\alpha$-терпенола (табл. 1$)$. Синтезированная фаза позволила разделить энантиомеры всех тестируемых соединений при их одновременном присутствии в анализируемой смеси.

Таблица 1. Разделение энантиомеров компонентов эфирных масел на индивидуальных и смешанной хиральных фазах.

\begin{tabular}{|c|c|c|c|c|}
\hline \multirow{2}{*}{ Соединение } & \multirow{2}{*}{$\begin{array}{c}\text { Температура } \\
\text { колонки, }{ }^{\circ} \mathrm{C}\end{array}$} & $\begin{array}{c}\text { 2,6-Ме-3-Pe- } \beta- \\
\text { CD }\end{array}$ & $\begin{array}{c}\text { 2,6-Ме-3-TFAc- } \gamma- \\
\text { CD }\end{array}$ & Chiramix \\
\hline$\alpha$-пинен & & 1.038 & 1.000 & 1.035 \\
Лимонен & 60 & 1.038 & 1.000 & 1.038 \\
Линаоол & 80 & 1.066 & 1.000 & 1.065 \\
$\alpha$-дамаскон & 110 & 1.028 & 1.028 & 1.025 \\
$\alpha$-ионон & 110 & 1.057 & 1.065 & 1.105 \\
$\delta$-жасмин лактон & 140 & 1.000 & 1.085 & 1.090 \\
$\gamma$-декалактон & 140 & 1.000 & 1.035 & 1.043 \\
\hline
\end{tabular}


В работе [5] синтезирован бинарный жидкокристаллический сорбент на основе 4-метокси-4-этокси-азобензола и ацетилированного $\beta$-циклодекстрина, массовая доля макроциклического гептакис $(2,3,6$-три-O-ацетил)- $\beta$-циклодекстрина составляла $10.25 \%$. Установлено, что макроциклическая добавка индуцирует образование спирально закрученной хиральной нематической фазы. На синтезированной фазе изучена сорбция 29 органических соединений разных классов (н-алканы, циклоалканы, арены, спирты, гетероциклы), среди них камфен, лимонен, бутандиол-2,3 оптически активны. Энантиоселективной по отношению к оптически активным веществам данная стационарная фаза является только в узком диапазоне температур $91-100^{\circ} \mathrm{C}$ изза затруднения образования комплекса макроцикл - сорбат в силу закрученности спирали нематической фазы.

Еще одна смешанная хиральная фаза для газовой хроматографии, содержащая в себе перметилированный циклодекстрин и D- или L-валин, синтезирована в работе [6]. При метилировании $\beta$-ЦД положение 6 защищали с помощью фторида тетрабутиламмония в растворе тетрагидрофурана, далее оставшиеся ОН-группы в 6 положении окисляли до -COOH. Валин ковалентно прививали в виде D- или L-валин-тpemбутиламида в 6 положение перметилированного $\beta$-ЦД посредством образования пептидной связи. Затем полученные производные циклодекстрина растворяли в полисилоксане OV-11 (35 \% фенил- и 65 \% метилсилоксана) и покрывали кварцевую капиллярную колонку. Способность синтезированной фазы к распознаванию энантиомеров оценивали путем ее сравнения с фазами, содержащими только перметилированный циклодекстрин (ПМ- $\beta$-ЦД) или только L-валин-трет-бутиламид («Chirasil$\mathrm{L}-\mathrm{Val}$ ). Исследование фаз провели для 117 оптически активных соединений разных классов, поделенных на три группы (рис.1). К первой группе относятся протеиногенные производные аминокислот, энантиомеры которых хорошо делятся на фазе «Chirasil-L-Val», это N-трифторацетилэтиловые и изопропиловые эфиры аминокислот. Ко второй группе относятся вещества с различными функциональными группами (производные миндальной кислоты, ароматические соединения, алифатические и ароматические спирты, диолы, сложные эфиры и их производные, лактоны, гидантионы, терпены, терппеноиды, их ацетаты), энантиомеры которых делятся на ПМ- $\beta$ ЦД. К третьей группе относятся 14 соединений (среди них трифторалкил манделаты, цинеол, камфора, карвон и ацетаты линалоола, цитронеллола, $\alpha$-терпинеола), энантиомеры которых до этого не разделяли на фазах, содержащих только один из селекторов.

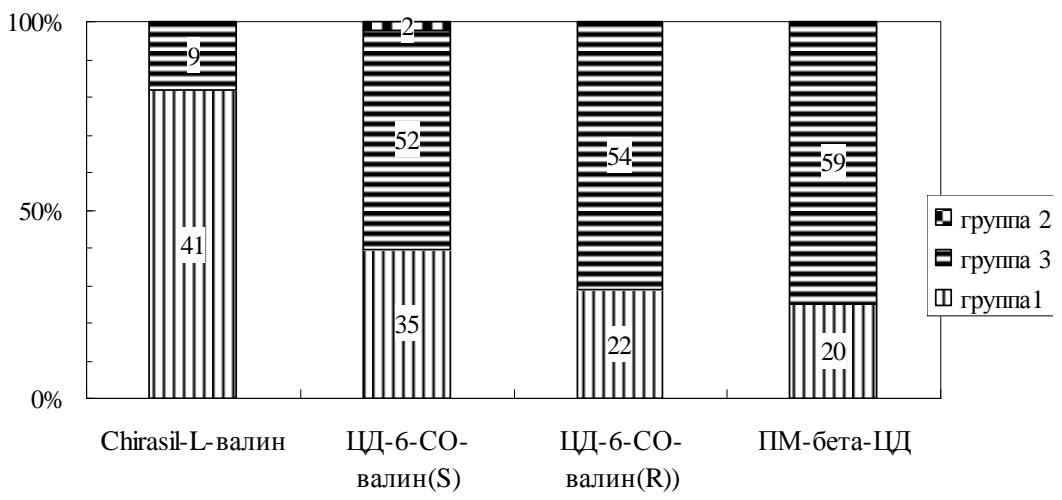

Рис. 1. Сравнение разделения энантиомеров на различных хиральных фазах на основе перметилированного циклодекстрина.

Стоит отметить, что исходная фаза ПМ- $\beta$-ЦД позволяет разделить энантиомеры 79 из 117 исследуемых соединений, тогда как «Chirasil-L-Val» только 50. При этом наиболее универсальной является смешанная фаза с $S$-валином, которая позво- 
ляет разделить энантиомеры 89 соединений, в том числе 2 соединения из группы 3 , энантиомеры которых не делятся на исходных фазах. На фазе с $R$-валином поделены энантиомеры 76 соединений (рис. 1). Среди двух синтезированных смешанных фаз поведение фазы с $S$-валином наиболее похоже на поведение фазы «Chirasil-L-Val». Для того чтобы еще больше увеличить количество разделяемых оптических изомеров на смешанной фазе, необходимо прививать валин к $\beta$-ЦД через спейсер, чтобы избежать попадания его в полости макроцикла и, тем самым, увеличить его доступность.

В качестве компонентов смешанной хиральной фазы в работе [7] использовали октакис-O-[(L-валин-третбутиламид)- $\mathrm{N}$-ацетил]-С-деценил-резорцинарен и монокис-O-октенил-перметил- $\beta$-циклодекстрин. Перметилированный $\beta$-циклодекстрин является селектором благодаря образованию комплексов включения, а производное резорцинарена - образованию водородных связей. Оба селектора пришиты на поли(гидроксиметил)диметилсилоксан с помощью Рt-катализируемой реакции гидроксилилирования алкенов в одном сосуде. Полученная таким образом смешанная фаза названа «Chirasil-Calixval-Dex». На фазе «Chirasil-Calixval-Dex», а также на фазах «Chirasil-Calixval» и «Chirasil-Dex», содержащих только один из селекторов, проводили энантиоразделение $\mathrm{N}$-трифторацетил-этиловых эфиров аминокислот. Стоит отметить, что фаза «Chirasil-Dex» позволяет разделить с приемлемыми коэффициентами разрешения производные только аланина, цистеина, серина, пролина, фенилаланина, в то время как «Chirasil-Calixval» позволяет разделять энантиомеры Nтрифторацетил-этиловых эфиров почти всех аминокислот, но не способна к энантиораспознаванию веществ, не образующих водородные связи. При использовании смешанной фазы авторы получили результаты, которые позволяют судить об аддитивном эффекте от каждого селектора, однако при этом наблюдается незначительное уменьшение коэффициентов разрешения в силу меньшей, по сравнению с индивидуальными селекторами, концентрацией каждого из селекторов в смешанной фазе.

Эти же ученые в более поздней работе [8] более подробно исследовали сорбент аналогичный «Chirasil-Calixval-Dex», но в отличие от предыдущей работы, синтезировали стационарную фазу не только производного резорцинарена c L-валином, но и с D-валином. Свойства смешанного хирального селектора не изменились. В работе [9] синтезирована схожая смешанная фаза с перметилированным $\beta$-ЦД и $\mathrm{N}$ ацил-L-валинамидом, однако пришивку последнего к макроциклу осуществляли через длинный углеводородный спейсер $\mathrm{C}_{11}$, a не на резорцинарен. Синтезированная фаза названа «Chirasil-DexVal-C 11 $_{1}$. Авторы исследовали и стационарные фазы, coдержащие отдельные хиральные селекторы «Chirasil-Val» и «Chirasil-Dex». Смешанная фаза обладает энантиоселективностью к производным аминокислот, как и «Chirasil-Val», и к недериватизированным спиртам, кетонам, углеводородам, как и «Chirasil-Dex». Также такая фаза значительно улучшает энантиораспознавание производного пролина, разделение энантиомеров которого затруднено на диамидных хиральных неподвижных фазах.

Повышение энантиоселективности и эффективности колонки при разделении энантиомеров с циклодекстриновыми фазами достигнуто при использовании ионных жидкостей, выступавших в качестве медиатора, в котором растворен хиральный селектор [10]. Ионные жидкости оказались хорошими растворителями для циклодекстрина и производных целлюлозы. Очень хорошие результаты получены в работе [11] при использовании в качестве хирального селектора раствора 6бутилимидозолил- $\beta$-циклодекстрина в 1,11-ди(3-метилимидозолил)-3,6,9-триоксандекане бис-трифторметилсульфонилимида. Такую стационарную фазу можно услов- 
но отнести к смешанным фазам, так как ионная жидкость усиливает энантиоселективность неподвижной фазы.

2. Смешанные хиральные неподвижные фазы в жидкостной хроматографии. В жидкостной хроматографии смешанные селекторы используют реже, первыми такими фазами можно назвать низкомолекулярные хиральные селекторы, содержащие два хиральных сайта различной природы. Одними из первых смешанную хиральную неподвижную фазу для ВЭЖХ в 1987 году синтезировали Hyun и Pirkle [12]. В coставе низкомолекулярного смешанного селектора были как $\pi$-основные (1-(6,7диметил)нафтил), так $\pi$-кислотные сайты (N-3,5-динитробензоил-) производных додециламина (ХНФ1). В качестве тестовых соединений использовали N-3,5динитробензоил-производные аминов и аминокислот. Коэффициент селективности разделения энантиомеров увеличивается с увеличением количества атомов в гомологическом ряду исследуемых соединений. Наличие жесткого каркаса в структуре молекулы аналита может либо усилить, либо уменьшить степень хирального распознавания, в зависимости от того, какая конформация является более предпочтительной. На рис.2а приведена структурная формула такого селектора.

Присутствие $\pi$-донорной нафтильной и $\pi$-акцепторной динитробензойной ароматических систем вокруг хирального фрагмента (с двумя хиральными атомами взаимодействие за счет образования водородных связей, обеспечивают необходимые для энантиораспознавания центры связывания. Природа потенциальных взаимодействий между молекулой селектора и молекулами сорбатов достаточно «универсальна».

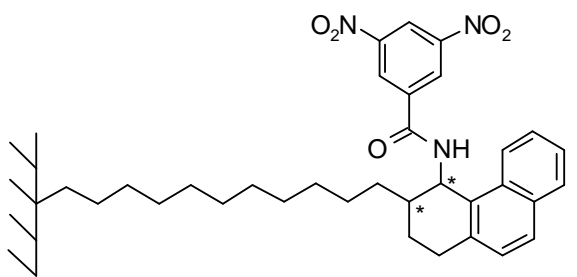

Рис. 2а. Структурная формула ХНФ 1, содержащей $\pi$-акцепторный и $\pi$ донорный фрагменты

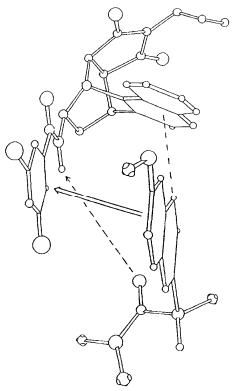

Рис. 2б. Модель хирального распознавания для селекторов, содержащих два хиральных центра

На рис. $2 б$ показана модель хирального распознавания для селекторов, содержащих два хиральных центра. Синтезированная ХНФ1 позволила разделить энантиомеры напроксена $(\alpha=2.25)$ и целого ряда других $\alpha$-арилпропионовых кислот (профенов). В качестве подвижной фазы использовали смесь гексана и пропанола-2, селективность разделения составила от 1.09 до 1.71 [13]. После обнаружения положительного эффекта конформационной жесткости молекулы селектора на его энантиоселективные свойства дальнейшее развитие ХНФ для разделения оптических изомеров заключалось в поиске других возможных структур, обладающих жестким углеродным скелетом. Так, поиск привел к синтезу хиральных селекторов с фрагментом циклического углеводорода бицикло[2.2.2]октана. Конформация этого фрагмента приводит к расположению $\pi$-донорного и $\pi$-акцепторного фрагмента под прямым углом друг к другу, формируя «сайт», распознающий пространственную конфигурацию оптических изомеров. Синтезированные ХНФ [14] на основе этих селекторов показали лучшую энантиоселективность по отношению к напроксену, чем предыдущая ХНФ1. 
Стоит отметить, что энантиоселективность хиральной фазы зависит не только от структуры молекулы хирального селектора, но также от состава подвижной фазы и от способа прививки селектора к силикагелевой матрице. Так, коммерческая фаза «WHELK-O1» представляет собой ХНФ с хиральным селектором, аналогичным ХНФ 1, но плотность прививки увеличена, а длина углеводородной «ножки» уменьшена. «WHELK-O 1» обладает лучшей селективностью благодаря увеличенной плотности пришивки, она оказалась подходящей для разделения энантиомеров широкого круга органических соединений. Описано разделение арилметанфосфонатов [15,16], $\gamma$-лактонов [17], $\mathrm{N}$-арилоксазолинов, $\mathrm{N}$-арилтиозолинов [18], ариламидов [19], арилкарбоновых кислот и оксикислот, арилкетонов, арилспиртов и олеиновых спиртов [20]. Хорошие энантиоселективные свойства «WHELK-O 1» по отношению к разным классам органических соединений использовали для разделения энантиомеров биологически активных соединений, входящих в состав ряда фармацевтических препаратов: нирванола, фталидомида, индапамида, тропикамида, бупивакаина, никардипина и пр. [20]. Фаза «WHELK-01» интересна не только для разделения энантиомеров широкого круга соединений, на ней исследуются механизм разделения энантиомеров, эти исследования активно продолжаются и в последние годы $[21,22]$.

Tambute A. с соавт. [23] синтезировали смешанную хиральную фазу для ВЭЖХ, содержащую $\pi$-донорный нафтильный и $\pi$-акцепторный динитробензойный ароматический сайты в виде производных тирозина. Исследователи отмечают, что такая хиральная фаза позволяет разделять энантиомеры как органических кислот, так и оснований, причем сайты, отвечающие за энантиораспознавание этих веществ, не мешают друг другу.

Авторы [24] синтезировали и исследовали смешанную хиральную фазу для ВЭЖХ на основе аминопропилсиликагеля. В качестве селекторов использовали (S)1-( $\alpha$-нафтил)-этиламин, связанный с $(\mathrm{S})$-фенилаланином или $(\mathrm{S})-\mathrm{N}-(3,5-$ динитробензоил)-фенилаланином, поэтому смешанная фаза содержала и $\pi$ донорную, и $\pi$-акцепторную составляющие. В работе исследованы неподвижные фазы, в которых в одном случае к силикагелю пришиты оба селектора, а в другом проводили предварительное сшивание двух селекторов и на силикагель прививали только через один из них. Кроме того, использовали сорбент, в котором механически смешаны сорбенты с каждым из селекторов в соотношении $1: 1$. В качестве аналитов использовали оптически активные соединения с ароматическими фрагментами в их структуре, такие как 2,2,2-трифтор-1-(9-антранил)этанол, бензоин, 2нафтилэтанол и др. Полученные результаты позволили авторам сделать вывод о том, что наиболее удачной смешанной ХНФ оказалась фаза, полученная механическим смешиванием двух сорбентов.

Позднее учеными из Италии и Китая [25-29] синтезированы смешанные ХНФ с использованием в качестве селекторов производных аминокислот, сшитых с помощью S-триазина. В молекуле 2,4,6-трихлор-1,3,5-триазина реакционная способность трех атомов хлора различается по мере их замещения в молекуле. Это позволяет присоединять к триазиновому кольцу различные хиральные фрагменты, тем самым получая полифункциональный селектор, способный проявлять интересные энантиоселективные свойства. Общая схема структуры таких биселекторов представлена на рис. 3. Селектор 1 представляет собой вещество А и триазин, селектор 2 - вещество Б.

Все синтезированные фазы протестированы на примере целого ряда оптически активных соединений, среди которых производные бинафтола, алкиларилкарбинолы, бензамиды, ацетамиды, анилиды. 


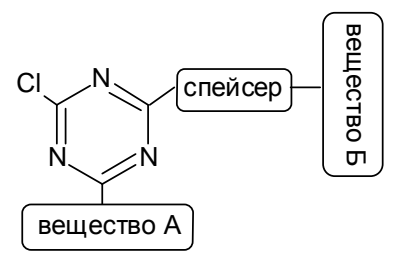

Рис. 3. Общая схема структуры биселектора на основе триазина [27].

При дальнейшем развитии подобных структур хирального селектора один из атомов хлора триазинового кольца использовали для ковалентной связи с аминопропилсиликагелевой матрицей В качестве двух других заместителей (введенных вместо двух атомов хлора) выступали С-защищенный трипептид валина и (S)-1-(1нафтил)этиламин, ДНБ-лейцин и $\mathrm{N}$-нафтоилфенилглицин [26,30]. Эти же авторы синтезировали хиральную неподвижную фазу с двумя селекторами, в качестве которых использовали производные аминокислот N-3,5-динитробензоил-лейцин и N-1нафтоилфенилглицин, сшитых с помощью остатка S-триазина. ХНФ показали высокую селективность по отношению к рацематам ДНБ-производных сложных метиловых эфиров аминокислот и аминоспиртов.

В работе [25] использовали оптически активные 1-(1-нафтил)этиламин (НЭЭ), (S)-N-3,5-динитробензоилфенилглицин (ДБФГ), $(S)-\mathrm{N}-3,5$-динитробензоил-лейцин (ДБЛ), ковалентно пришитые к силикагелю с помощью остатка $S$-триазина в различном сочетании из R- и S-изомеров. Синтезированы четыре неподвижные фазы с двумя селекторами:

$$
\begin{aligned}
& 1 \text { - }(S) \text {-НЭЭ; }(S) \text {-ДБЛ } \\
& 2 \text { - }(R) \text {-НЭЭ; }(S) \text {-ДБЛ } \\
& 3 \text { - }(S) \text {-НЭЭ; }(S) \text {-ДБФГ } \\
& 4 \text { - }(R) \text {-НЭЭ; }(S) \text {-ДБФГ }
\end{aligned}
$$

Проведено сравнение энантиоразделяющей способности каждой из них на примере ряда оптически активных веществ, среди которых 3,5-динитрофенилпроизводные 1-арилпропионовых кислот, (алкил-арил)-метиламины, 3,5динитробензоил-производные (алкил-арил)-метиламинов, 3,5-динитроанилид ибупрофена. С точки зрения эффективности и универсальности для разделения энантиомеров кислотного характера лучшей оказалась фаза, содержащая $(S)$-НЭЭ и $(S)$ ДБЛ. Авторы предположили, что конформация и, следовательно, энантиоразделяющие способности смешанной хиральной фазы сильно зависят от «удаленности хиральности» в молекулах селекторов.

В целом, положительные результаты по энантиоразделению рацематов как $\pi$ донорных, так и $\pi$-акцепторных ароматических соединений во всех работах данных авторов позволяют говорить о том, что данная система выступает в роли истинного смешанного селектора с полной независимостью действий каждого из них, благодаря присутствию S-триазина, связывающего селекторы между собой.

В работе [31] исследовано разделение энантиомеров 56 ароматических соединений различной структуры на хиральных сорбентах, полученных модифицированием аминосиликагеля: (2S,3S)-1-(бензилокси)-4-хлор-1,4-диоксибутан-2,3-диилдибензоатом (селектор 1), и $(1 \mathrm{R}, 2 \mathrm{R})-1,2-$-дифенил-2-(3-фенилуридо)этил-4изоцианатофенилмочевиной и их смесью (селектор 3). Показано, что смешанная хиральная фаза уступает по энантиоселективности фазам с каждым из селекторов. Это связано с меньшим содержанием индивидуальных селекторов на поверхности сорбента и, возможно, с обращением устойчивости образующихся диастереомерных 
комплексов для взятых селекторов. В результате в присутствии смеси селекторы 1 и 2 нивелируют энантиоселективность друг друга.

В 1994 г. Anne-Fraqoise Aubry с соавт. [32] синтезировали смешанную хиральную неподвижную фазу для ВЭЖХ на основе белков. В качестве хиральных селекторов использовали сывороточный альбумин человека (ЧСА) и $\alpha_{1}$-кислый гликопротеин (орозомукоид, АГП). Выбор этих белков обусловлен тем, что при разделении оптических изомеров они дополняют друг друга: ЧСА используют для соединений кислотного характера, АГП - для основного характера. Предварительно синтезировали сорбенты с каждым из белков по отдельности. Синтез проводили путем цикличной промывки колонки с силикагелем, активированным 3глицидоксипропилтриметоксисиланом, растворами белков в фосфатном буферном растворе (50 мМ, pH 7.5) в течение 24 часов. Далее полученные таким образом сорбенты смешали в эквивалентных количествах и заполнили смесью хроматографическую колонку. Содержание ЧСА в смешанной фазе составило 80 мг/г $\mathrm{SiO}_{2}$, АГП -

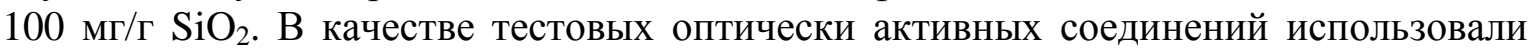
катионные, анионные и нейтральные соединения, среди которых: темазепам, оксазепам, окспренолол, пропранолол, супрофен, кетопрофен, дизопирамид, прометазин, гексобарбитал, пентобарбитал, бензоин, варфарин, кеторолак, верапамил, мефлохин, анаприлин.

Разделение энантиомеров проводили на трех колонках: со смешанной ХНФ и с каждым из белков по отдельности. Разделение оптически активных аналитов на смешанном сорбенте происходит, если их энантиораспознавание возможно хотя бы на одном из белков смешанной фазы, тем самым, число разделяемых соединений на смешанной фазе представляет собой «сумму» соединений, разделение которых возможно на каждом из белков, входящих в его состав по отдельности. На смешанной фазе из исследованных соединений не были разделены только энантиомеры гексобарбитала, хотя его энантиораспознавание возможно на колонке с каждым из протеинов по отдельности. В этом случае на смешанном сорбенте, наблюдали и меньшее удерживание соединений. Наилучшие результаты разделения энантиомеров достигаются в присутствии только одного из белков. Вероятно, вовлечение сразу двух белков в энантиораспознавание приводит к тому, что увеличивается количество как хиральных, так и нехиральных взаимодействий, в результате чего суммарная энантиоселективность фазы снижается.

Еще одним классом хиральных селекторов, использованных для синтеза смешанных ХНФ в ВЭЖХ, стали полисахариды, в частности, производные целлюлозы и амилозы. В работе [33] использовали для синтеза $n$ - и $\boldsymbol{M}$-метилбензоил целлюлозу, 3,5-диметилфенилкарбамат целлюлозы. Производные целлюлозы прививали на силикагель, предварительно модифицированный 3-аминопропилтриэтоксисиланом. Авторы использовали два способа получения смешанной фазы: одновременная прививка двух производных целлюлозы и механическое смешивание сорбентов, содержащих каждое из производных по отдельности. В качестве подвижной фазы использовали смесь гексана и изопропанола в объемном соотношении $90: 10$. В качестве тестовых соединений были взяты 28 ароматических веществ различного строения. Авторы отмечают, что полученные значения коэффициентов селективности практически не зависят от способа получения смешанной фазы, однако для колонки с механически смешанными сорбентами характерно небольшое уменьшение удерживания веществ, что почти не сказывается на разделении энантиомеров. Небольшое снижение селективности смешанной фазы для веществ, разделение энантиомеров которых возможно только на одном из производных, по сравнению с фазами только с одним производным целлюлозы объясняется уменьшением его концентрации на 
сорбенте за счет наличия другого производного. Варьируя соотношение селекторов на сорбенте, можно добиться желаемых значений селективности исследуемых аналитов.

Совместное применение в ВЭЖХ нашли и фенилкарбамат целлюлозы и 4метилбензоат целлюлозы в работе [34]. Причем трис-фенилкарбамат целлюлозы и трис-4-метилбензоат целлюлозы наносили на силикагель путем физической адсорбции, а 2,3-бис-(фенилкарбамат)-целлюлозу и 2,3-бис-(4-метилбензоат)-целлюлозу путем ковалентной сшивки. В качестве аналитов использовали: оксид трансстильбена, бензоин, празиквантел, бендрофлуметиазид, основание Трегера, варфарин, N-2,4-ДНФ-глутаминовая кислота. Показано, что сорбенты и с «покрытыми», и с «привитыми» производными целлюлозы обладают энантиоселективностью каждого из хиральных компонентов сорбента. Энантиоселективность смешанного сорбента является средней между энантиоселективностями каждого из его компонентов. В зависимости от способа синтеза на поверхности сорбентов образуются разные «хиральные сайты», что приводит к тому, что сорбенты с одними и теми же хиральными селекторами, но полученными разными способами, имеют разную способность к разделению энантиомеров тестовых соединений.

Производные амилозы трис-фенилкарбамат и трис-бензоат в качестве селекторов неподвижной фазы использовали в [35], их соотношение в привитом слое на поверхности аминированного силикагеля составляло $1: 1$. В качестве исследуемых веществ использовали 35 соединений ароматической структуры, среди которых талидомид, (2-циано-этил)-4-нитробензол, 4-(2-аминоэтил)-метокситолуол. Установлено, что разделение энантиомеров изученных веществ на смешанном сорбенте лучше по сравнению с сорбентами, содержащими только один селектор.

В работе [36], для получения смешанной хиральной фазы использовали производные целлюлозы: трис-(4-метилфенилкарбамат) целлюлозу (МФКЦ), трис(фенилкарбамат) целлюлозу (ФКЦ), трис-(4-хлорфенилкарбамат)-целлюлозу (ХФКЦ); в качестве производных амилозы: трис-(3,5-диметилфенилкарбамат)амилозу (ДМФКА). Синтезированы 4 хиральные фазы с каждым из производных, привитых на 3-аминопропилсиликагель (ХНФ 1 - 4 соответственно) и 3 смешанные фазы, содержащие производное амилозы и одно из производных целлюлозы в соотношении 1:1, привитых на 3-аминопропилсиликагель (МФКЦ-ДМФКА (5), ФКЦДМФКА (6), ХФКЦ-ДМФКА (7)). Свойства ХНФ исследовали на примере 33 оптически активных вещества разных классов, наиболее часто используемых для тестирования сорбентов с полисахаридами. Оказалось, что смешанная ХНФ 5 обладает энантиоселективностью, схожей с ХНФ 1, но лучшей, чем у фазы 4. ХНФ 6 похожа на фазу 4, но более селективна, чем фаза 2. В целом, смешанные фазы обладают хорошей способностью к разделению оптических изомеров, но в большинстве случаев величина разрешения пиков энантиомеров, находится между значениями, полученными для индивидуальных селекторов. Смешанные селекторы расширяют выбор растворителей для подвижной фазы: энантиомеры с ХНФ на основе производными ХФКЦ и ДМФКА (7) можно элюировать смесью н-гексан/этанол, 70/30, тогда как добавка этанола в подвижную фазу при использовании сорбента, содержащего только ХФКЦ (3), невозможна. Разделение оптических изомеров на ХНФ 5 возможно при элюировании $100 \%$ этанолом.

Авторами обзора впервые предложена смешанная хиральная фаза, где селекторами служили макроциклические антибиотики эремомицин и ванкомицин, одновременно иммобилизованные на поверхности аминопропилсиликагеля [37]. Хиральный сорбент с эремомицином позволяет разделять энантиомеры недериватизированных аминокислот [38], но не селективен по отношению к такому классу веществ, как 
$\beta$-блокаторы. В то время как хиральный сорбент с ванкомицином (коммерческая колонка Chiroboitic V) [39,40] широко используется для разделения энантиомеров блокаторов, но не позволяет разделить изомеры аминокислот. Смешанный селектор сочетает свойства двух использованных макроциклических антибиотиков. Использование такой хиральной неподвижной фазы позволяет провести на одной колонке селективное разделение энантиомеров двух важных классов соединений, используемых в медицине, $\beta$-блокаторов и аминокислот с высокими значениями разрешения пиков за достаточно короткое время (не более 10 мин). Сравнение разделения энантиомеров $\beta$-блокаторов на силикагеле, модифицированном смесью эремомицина и ванкомицина $(1: 1)$ и только ванкомицина показаны в табл. 2. При разделении рацемических смесей аминокислот со смешанным селектором хорошее разрешение пиков (больше 2) получено для триптофана и фенилаланина, имеющих в своем составе индольное (бензольное) кольцо, а также для метионина, содержащего атом серы. В отличие от колонки, заполненной силикагелем, модифицированным только эремомицином, не удается разделить энантиомеры аминокислот, не содержащих ароматические фрагменты, такие как аланин, валин, серин, лизин, аргинин, норвалин. Они практически не удерживаются на колонке, это может быть связано с меньшим вкладом в удерживание и разделение энантиомеров на сорбенте с двумя хиральными селекторами электростатических взаимодействий. Основные закономерности разделения веществ на смешанном сорбенте и сорбентах с одним антибиотиком сохраняются.

Таблица 2. Разделение энантиомеров $\beta$-блокаторов на смешанном сорбенте и на силикагеле, модифицированном ванкомицином, (коммерческая колонка Chirobiotic V), скорость потока $1 \mathrm{~cm}^{3} /$ мин, спектрофотометрический детектор, 270 нм.

\begin{tabular}{|c|c|c|c|c|c|c|}
\hline Колонка & \multicolumn{2}{|c|}{$\begin{array}{c}\text { Силикагель/эремомицин-ванкомицин } \\
(10 \text { см) }\end{array}$} & \multicolumn{3}{c|}{ Chiroboitic V (25 см) } \\
\hline $\begin{array}{c}\text { Подвижная } \\
\text { фаза }\end{array}$ & $\begin{array}{c}(78 / 19 / 3) \text { ацетонитрил / метанол / 0.1\% } \\
\text { триэтиламиноацетат (pH 5) }\end{array}$ & \multicolumn{2}{c|}{$\begin{array}{c}\text { (90/10) метанол / 0.1\% триэти- } \\
\text { ламиноацетат (pH 5) }\end{array}$} \\
\hline Вещество & $k$ & $R_{s}$ & $\alpha$ & $k$ & $R_{s}$ & $\alpha$ \\
\hline Пиндолол & 6,12 & 0.91 & 1.15 & 10.93 & 0.91 & 1,07 \\
\hline Альпренолол & 3.87 & 1.46 & 1.28 & 8.80 & 1.19 & 1,08 \\
\hline Окспренолол & 3.87 & 1.53 & 1.25 & 8.71 & 0.97 & 1,07 \\
\hline Атенолол & 12.19 & 0.57 & 1.39 & 13.72 & 0.95 & 1,07 \\
\hline
\end{tabular}

1 -фактор удерживания первого энантиомера

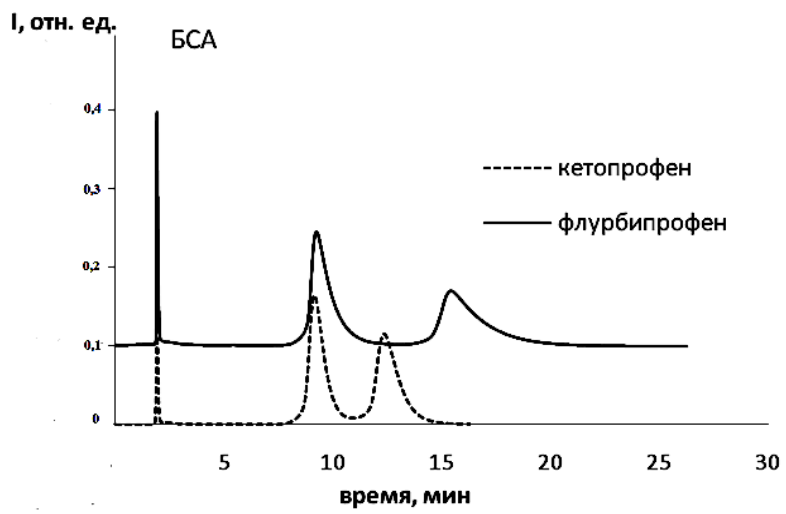

Рис. 4. Хроматограммы кетопрофена и флурбипрофена в присутствии БСА в исследуемом растворе. Сорбент: силикагель/эремомицин-БСА. Подвижная фаза: метанол/ $\mathrm{KH}_{2} \mathrm{PO}_{4}$ (40 мМ, pH 4.5), 60/40, $0.5 \mathrm{~cm}^{3} /$ мин, 280 нм. 
Синтезирован смешанный сорбент, содержащий антибиотик эремомицин и белок - бычий сывороточный альбумин, на нем разделены энантиомеры профенов и бензоина [41]. Показано, что ключевую роль в качестве селектора играет эремомицин. Меньший вклад БСА в распознавание энантиомеров, возможно, связан с тем, что, в отличие, от эремомицина, белок закреплен на поверхности сорбента методом физической адсорбции и его содержание меньше. Однако БСА играет важную роль при определении энантиомеров в биологических жидкостях. Размер молекул БСА превышает размер пор силикагеля, поэтому он адсорбируется на поверхности смешанного хирального сорбента, тем самым защищая его поры от проникновения других крупных молекул. Это позволяет разделять и определять энантиомеры профенов (как показано, на примере кетопрофена, рис. 4) на смешанном хиральном сорбенте с эремомицином и БСА в присутствии маркерных белков с диапазоном молекулярных масс 13.7-669 кДа.

\section{Заключение}

Таким образом, смешанные стационарные фазы для разделения энантиомеров веществ достаточно широко применяются как в жидкостной, так и в газовой хроматографии. В качестве хиральных селекторов в газовой хроматографии чаще всего выступают производные $\beta$-циклодекстрина, реже производные аминокислот. В жидкостной хроматографии селекторами могут быть белки, производные полисахаридов, производные аминокислот, макроциклические антибиотики. Сочетание селекторов в неподвижной фазе определяется в значительной степени двумя факторами: способностью дополнять энантиоселективные свойства друг друга и схожесть их иммобилизации на матрицу (чаще всего это силикагель). Как правило, смешанные стационарные фазы проявляют среднюю способность к энантиораспознаванию по сравнению с фазами с одним исходным селектором, но выявлены случаи и увеличения суммарной энантиоразделяющей способности. Основным достоинством смешанных хиральных фаз является расширение круга разделяемых соединений и, тем самым, унифицирование такой фазы.

\section{Список литературы/References}

1. Qi S., Ai P., Wang C., Yuan L., Zhang G., Sep. Purif. Technol. 2006, Vol. 48, pp. 310-313.

2. Nie M.Y., Zhou L.M., Wang Q.H., Zhu D.Q., Chromatographia, 2000, Vol. 51, No. 11/12, pp. 736-740.

3. Tamogami S., Awano K., Amaike M., Takagi Y. et al., Flavour Fragr. J., 2001, Vol. 16, pp. 349-352.

4. Bayer M., Mosand A., Flavour Fragr. J., 2004, Vol. 19, pp. 515-517.

5. Onuchak L.A., Burmatnova T.S., Spiryaeva E.A., Russian Journal of Physical Chemistry A, 2012, Vol. 86, Issue 8, pp. 1308-13176.

6. Stephany O., Dron F., Tisse S., Martinez A. et al., J. Chromatogr. A, 2009, Vol. 1216, pp. 4051-4062.

7. Ruderisch A., Pfeiffer J., Schurig V., J. Chromatogr. A, 2003, Vol. 994, pp. 127-135.

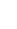

8. Levkin P.A., Ruderisch A., Schurig V., Chirality, 2006, Vol. 18, pp. 49-63.

9. Levkin P.A., Levkina A., Schurig V., Anal. Chem., 2006, Vol. 78, pp. 5143-5148.

10. Poole C.F., Lenca N., J. Chromatogr. A, 2014, Vol. 1357, pp. 87-109.

11. Huang K., Zhang X.Y., Armstrong D.W., J. Chromatogr. A, 2010, Vol. 1217, No 6, pp. 5261-5273.

12. Hyun M.H., Pirkle W.H., J. Chromatogr. A, 1987, Vol. 393, pp. 357-365.

13. Pirkle W.H., Welch C.J., Lamm B., J. Org. Chem., 1992, Vol. 57, No 14, pp. 3854-3860.

14. Pirkle W.H., Liu Y., J. Chromatogr. A, 1996, Vol. 736, pp. 31-38.

15. Pirkle W.H., Brice L.J., Tetrahedron.: Asymm., 1996, Vol. 7, No 8, pp. 2173-2176.

$$
\text { Asymm., 1996, Vol. 7, No 8, pp. } 2173-2176 .
$$


16. Pirkle W.H, Brice L.J., Caccamese S., Principato G. et al., J. Chromatogr. A, 1996, Vol. 721, pp. 241-246.

17. Pirkle W.H., Spence P.L., J. Chromatogr. A, 1997, Vol. 775, pp. 81-90.

18. Pirkle W.H., Koscho M.E., Wu Z., J. Chromatogr. A, 1996, Vol. 726, pp. 91-97.

19. Pirkle W.H., Gan K.Z., Brice L.J., Tetrahedron Asymm., 1996, Vol. 7, No 10, pp. 28132816.

20. Welch C.J., Szczerba T., Perrin S.R., J. Chromatogr. A, 1997, Vol. 758, pp. 93-98.

21. Zhao C., Cann N.M., Anal. Chem., 2008, Vol. 80, pp. 2426-2438.

22. Zhao C., Cann N.M., J.Chromatog. A, 2007, Vol. 1149, pp. 197-218.

23. Tambute A., Siret L., Caude M., Begos A. et al., Chirality, 1990, Vol. 2, pp. 106-119.

24. Oliveros L., Minguillon C., Desmazieres B., Desbene P.-L., J. Chromatogr., 1991, Vol. 543 , pp. $276-286$.

25. Iuliano A., Attolino E., Salvadori P., Tetrahedron: Asymmetry, 2002, Vol. 13, pp. $1805-$ 1815.

26. Iuliano A., Lecci C., Salvadori P., Tetrahedron: Asymmetry, 2003, Vol. 14, pp. 1345 1353.

27. Iuliano A., Attolino E., Salvadori P., Eur. J. Org. Chem., 2001, pp. 3523-3529.

28. Lin C.-E., Lin C.H., Li F.K., J. Chromatogr. A, 1996, Vol. 722, pp. 189-198.

Федорова Ирина Александровна - аспирант кафедры аналитической химии, Московский Государственный Университет им. М.В. Ломоносова, Химический факультет, Москва

Шаповалова Елена Николаевна - доцент кафедры аналитической химии, к.х.н., Московский Государственный Университет им. М.В. Ломоносова, Химический факультет, Москва

Шпигун Олег Алексеевич - чл.-корр. РАН, профессор кафедры аналитической химии, д.х.н., Московский Государственный Университет им. М.В. Ломоносова, Химический факультет, Москва
29. Lin C.-E., Li F.K., J. Chromatogr. A, 1996, Vol. 722, pp. 199-209.

30. Iuliano A., Pieroni E., Salvadori P., J. Chromatogr. A, 1997, Vol. 786, pp. 355-360.

31.Wei W.-J., Deng H.-W., Chen W., Bai Z.W. et al., Chirality, 2010, Vol. 22, pp. 604-611.

32.Aubry A.-F., Markoglou N., Descorps V., Wainer I.W. et al., J. Chromatogr. A, 1994, Vol. 685, pp. 1-6.

33. Zhang T., Francotte E., Chirality, 1995 , Vol. 7, pp. 425-433.

34. Chen X., Zou H., Ni J., Feng S., J. Sep. Sci., 2003, Vol. 26, pp. 29-36.

35. Chen J., Duan R., Chen W., Zhang J.et al., Curr. Analyt. Chem., 2013, Vol. 9, No 1, pp. 128-134.

36. Wang Z.-Q., Liu J., Chen W., Bai Z.-W., J. Chromatogr. A, 2014, Vol. 1346, pp. 57-68.

37. Fedorova I.A., Shapovalova E.N., Shpigun O.A., J. Analyt. Chem., 2017, Vol. 72, No 1, pp. 76-82.

38. Kuznetsov M.A., Nesterenko P.N., Vasiyarov G.G., J. Analyt. Chem., 2008, Vol. 63, No 1, pp. 57-64.

39. Ananieva I.A., Diss. cand. chem. science, M., 2001. 150 p.

40. Bosakova Z., Curınova E., Tesarova E., J. Chromatogr. A, 2005, Vol. 1088, pp. 94-103.

41. Fedorova I.A., Shapovalova E.N., Shpigun O.A., Staroverov S.M., JFDA, 2016, Vol. 24, pp. 848-854.

Fedorova Irina A. - graduate student of the Department of Analytical Chemistry Lomonosov Moscow State University, Chemistry Faculty, Moscow

Shapovalova Elena N. - Associate Professor of the Department of Analytical Chemistry Lomonosov Moscow State University, Chemistry Faculty, Moscow

Shpigun Oleg A. - corresponding Member of RAS, Professor of the Department of Analytical Chemistry, Lomonosov Moscow State University, Chemistry Faculty, Moscow 